\title{
ReCent DeVelopments IN EUROPEAN COMPANY AND BUSINESS LAW
}

\author{
INGO SAENGER*
}

[Company Law, Business Law and Capital Markets Law in Europe are widely influenced by a multitude of regulations and directives as well as by the case-law of the European Court of Justice. There have already been numerous cases in which the ECJ gave fresh impetus to several developments which were slowed down before by specific statutory provisions of individual Member States. The most recent reason for a special focus on the up-to-date developments are the prevailing dynamics in EU-wide harmonization of law in general and in particular the Action Plan on "Modernising Company Law and Enhancing Corporate Governance in the EU" presented by the European Commission.]

\section{INTRODUCTION}

The outstanding importance of the European Community Law for the legal system of the individual member states of the European Union needs no further accentuation. This is especially true for Company and Business Law which provides the legal framework for business operations. But several problems remain as far as the legal treatment of companies which engage in cross-border European business transactions is concerned. What are the legal rules applying to their registration; permanent establishment; company structure; minimum capital; liability; disclosure; creditor and consumer protection; spin-off or merger? There may be special interest in a company's cross-border business transactions which has to be provided

\footnotetext{
${ }^{*}$ Prof. Dr. Ingo Saenger holds the chair for Civil Law, Procedural Law and Corporate Law and is the director of the Institute for International Business Law at the University of Münster (Germany) and is a judge at the North Rhine-Westphalian court of appeal at Hamm (saenger@uni-muenster.de). This article is based on the manuscript of a lecture held at the School of Law of Deakin University on October $19^{\text {th }}$, 2004. Many thanks for his thoughts and insights on this piece go to Jean J du Plessis.
} 
for right from the moment the company is incorporated. This may especially require providing separate forms of European companies. Another important factor regarding the incorporation of companies and their cross-border transactions are company taxes, which significantly influence the choice of location and the company's investment activity. The selective choice of a legal system has gained an even greater importance concerning issues like incorporation expenditures; minimum capital; tax burdens; corporate governance; piercing the corporate veil; and rights of codetermination since the "incorporation doctrine" has become so prominent over recent times. Those matters are widely influenced by a multitude of regulations and directives as well as by the case-law of the European Court of Justice (ECJ). There have already been numerous cases, in recent times e.g. the Centros, Überseering and Inspire Art ${ }^{2}$ which concerned the cross-border transfer of the company's seat, in which the ECJ gave fresh impetus to several developments which were slowed down before by specific statutory provisions of individual Member States. The most recent reason for a special focus on the up-to-date developments are the prevailing dynamics in EU-wide harmonization of law in general and in particular the Action Plan on "Modernising Company Law and Enhancing Corporate Governance in the EU"3 presented by the European Commission.

\section{OVERVIEW OF EUROPEAN COMPANy LaW}

Company Law in general is the law of private special purpose associations. ${ }^{4}$ Having an existence separate, but alongside this are fields of law, which do not directly regulate such private associations and therefore cannot be considered to be Company Law in its original sense. Still those fields of law like Accounting Regulations; Corporate Group Law; Antitrust Law; (other) competition laws; and Tax Law are typically of great importance to companies. All of those fields of law can be summarized in the term of Enterprise Law. ${ }^{5}$ If those laws and regulations are based on a European framework one can speak of European Enterprise Law. ${ }^{6}$ The most important fundamental basis of law on a European level is the EC (Treaty establishing the

\footnotetext{
${ }^{1}$ Compare Part C.

${ }^{2}$ For "Inspire Art" compare note 86. For case law of the BGH [German Federal Supreme Court of Justice] concerning European Company Law compare Hartwig Henze, Europäisches Gesellschaftsrecht in der Rechtsprechung des Bundesgerichtshofs, 56 DER BETRIEB (ZEITSCHRIFT) 2159, 2159 ff. (2003).

${ }^{3}$ Compare Part F.

${ }^{4}$ Compare Herbert Wiedemann, GeSEllschaftSRECHT 3 ( $1^{\text {st }}$ ed. 1980$)$

5 Kurt Ballerstedt, GmbH-Reform, Mitbestimmung, Unternehmensrecht, 135 ZEITSCHRIFT FÜR DAS GESAMTE HANDELS- UND WIRTSCHAFTSRECHT 478, 484 (1971), tried to define this term in general. It has to be agreed with KARSTEN SCHMIDT, GESELLSCHAFTSRECHT ( $4^{\text {th }}$ ed. 2002) $\S 1$ II. 4 . b, that the term has not yet been clearly defined after all (see also Martina Deckert, Europäisches UnternehmensrechtStand und Probleme, 7 EUROPÄISCHES WIRTSCHAFTS- UND STEUERRECHT 265 n. 2 (1996)). Compare the proposed structure by MARCUS LUTTER, EUROPÄISCHES UNTERNEHMENSRECHT 4 ( $4^{\text {th }}$ ed. 1996). Concerning the distinguishing between capital markets law compare MATHIAS HABERSACK, EUROPÄISCHES GESELLSCHAFTSRECHT n. 4 (1999) and SCHMIDT, id. at § 1 II. 3.

${ }^{6}$ Any agreements based on Art. 293 EC can be counted in as well; compare WOLFGANG KILIAN, EUROPÄISCHES WIRTSCHAFTSRECHT n. 477 (1996).
} 
European Community) as a part of the primary legislation. ${ }^{7}$ The EC (Treaty establishing the European Community) contains the most general regulations about the European Community and how it is constituted as well as regulations which can be assigned to Company and Enterprise Law. In contrast to law making by Regulations, which is of no major significance in European Company and Enterprise Law, ${ }^{8}$ law making by Directives is of great importance (Art. 249 (3) EC). ${ }^{9}$

\section{A Freedom of Establishment}

The freedom of establishment is provided for in Art. 43 EC. Due to Art. 48 (1) EC it can also be applied to companies, which comply with Art. 48 (2) EC. The general principle of the freedom of establishment has been imbedded in the European Company and Enterprise Law for a long time, especially in the van Gend \& Loos cases. ${ }^{10}$ The principle of freedom of establishment has been used as a yardstick by the ECJ in various fields of the European Company and Enterprise Law to decide about the applicability of national state laws. ${ }^{11}$ Once a related case comes up, first of all it has to be decided upon whether the scope of protection ${ }^{12}$ of the freedom of establishment is applicable. In doing so it has to be distinguished between the factual and the personal scope of protection. Within the factual scope of protection it has to be clarified whether the affected activity is indeed an act of free movement (Art. 43 (1) (1) EC). Art. 43 (2) and Art. 43 (1) (2) EC therefore try to define the act of free movement. Apart from this definition, the ECJ often ${ }^{13}$ defines the freedom of establishment as "the actual pursuit of an economic activity through a fixed establishment in another Member State for an indefinite period". This is done without noticing how this definition should be interpreted in context of the formal definition of the freedom of establishment in Art. 43 (2), (1) (2) EC. The ECJ seems to assume that the formal definition in Art. 43 (1) (2), (2) EC does not exclusively determine a definition of the freedom of establishment but instead provides a basis for an interpretation and enhancement of the definition in Art. 43 (1) (1) EC. However, it remains questionable whether this interpretation could easily be reconciled

\footnotetext{
${ }^{7}$ Regarding the term and the individual parts compare ALBERT BLECKMANN, EUROPARECHT n. $526\left(6^{\text {th }}\right.$ ed. 1997).

${ }^{8}$ Regulations and Directives are part of the secondary law, compare BLECKMANN, supra note 7, at n. $527 \mathrm{ff}$.

${ }^{9}$ Peter Wiesner provides a good overview about all Directives concerning the European Enterprise Law in his series of articles in EUROPÄISCHE ZEITSCHRIFT FÜR WIRTSCHAFTSRECHT, compare 270 (1992); 500 (1993); 588 (1994); 821 (1995); 619 (1998) and Peter Wiesner, 56 BETRIEBSBERATER (ZEITSCHRIFT), issue 44, addendum 8 (2001). The important cases of the ECJ concerning European Company and Enterprise Law are documented and commented within CASEBOOK EUROPÄISCHES GESELLSCHAFTS- UND UNTERNEHMENSRECHT (Ingo Saenger et. al ed., 2002).

${ }^{10}$ Compare e.g. Peter Behrens, Das Internationale Gesellschaftsrecht nach dem Centros-Urteil des $E u G H, 19$ PRAXIS DES INTERNATIONALEN PRIVAT- UND VERFAHRENSRECHTS (ZEITSCHRIFT) 323, n. 10, 13 (1999). Compare ECJ, Rec. 1974, 631 "Reyners", in which the ECJ provided for the freedom of establishment even against the very wording of the former Art. 43 in the Treaty of Amsterdam.

${ }_{11}$ Especially applicable concerning individual national tax regulations, compare Ulrich Klinke, Europäisches Unternehmensrecht und EuGH - Die Rechtsprechung in den Jahren 1993-1994, 24 ZEITSCHRIFT FÜR UNTERNEHMENS- UND GESELLSCHAFTSRECHT 373, 391 f. (1995).

${ }^{12}$ This approach is originally taken from the dogmatic of German Basic Rights but can be transferred to the fundamental rights.

${ }^{13}$ Compare ECJ, Rec. 1991, I-3905 “Factortame II”, para 20.
} 
with the formal definition in Art. 43 (1) (1) EC, namely that the right of establishment shall be interpreted "within the framework of the provisions set out below". As far as the second part of the protection is concerned, namely the personal scope of protection, due to Art. 48 (1) EC the freedom of establishment shall be applicable to companies, which comply with Art. 48 (2) EC. ${ }^{14}$ In most of the cases it is quite sufficient to state that the affected company corresponds with the requirements of Art. 48 (2) EC.

If the scope of protection of the freedom of establishment is applicable, it will be determined in a second step whether the given procedure is indeed a restriction as referred to in Art. 43 EC. Though, the most recent cases decided by the ECJ can only be understood if one is familiar with the development of the cases dealing with fundamental freedoms in general. One has to be especially aware of the fact that fundamental freedoms have undergone a development from just being a discrimination ban ${ }^{15}$ to being a ban on restrictions. If fundamental freedoms are understood as being only a discrimination ban, they will not provide for more than the right not to be discriminated against by a state on the basis of foreign citizenship. If a citizen of a Member State is subject to a regulation of another Member State, which treats him worse than a domestic citizen (e.g. the requirement of a permission to take up an activity), he will be able to deny the application of such a regulation based on the principles of fundamental freedoms. Discrimination in general requires two comparable ${ }^{16}$ circumstances to be treated differently. Those different treatments need to be based on citizenship. Therefore it is required as a basic principle that the regulation uses the citizenship of a person or a company's seat ${ }^{17}$ as a link to a different treatment. This is called direct and overt discrimination. But discrimination can also be indirect or covert. In such cases the national regulation is not based on citizenship but instead links to other criteria which are still typically met by foreigners. Therefore it can be called a discrimination against foreigners based on citizenship as well. That is called covert discrimination. ${ }^{18}$ If one takes a close look at a scenario where a Member State even treats his very own citizens in an inappropriate way it becomes clear that fundamental freedoms - if understood as just being a discrimination ban will not be of any help to the national citizens at all. They could only demand to be treated as equally inappropriate as anyone but could not question the regulation itself.

\footnotetext{
${ }^{14}$ Regarding those two regulations GÜNTHER CHRISTIAN SCHWARZ, EUROPÄISCHES GESELLSCHAFTSRECHT n. 147 ff. (2000).

${ }^{15}$ Sometimes also called no discrimination against domestic citizens (compare General Attorney, Rec. 1999, I-1459 "La Pergola", 1468; STEFAN UlRICh PIEPER, ANDRes SCHOllmeIER \& Dieter KRIMPHOVE, EUROPARECHT - DAS CASEBOOK 221 ( $2^{\text {nd }}$ ed., 2000).

${ }^{16}$ Comparability is especially important in cases concerning tax law, compare ECJ, Rec. 1999, I-6161 "St. Gobain" para 45.

${ }^{17}$ The company's seat is treated just like the citizenship of an actual person (compare Art. 48 (1) EC), compare ECJ, Rec. 1986, 273.

${ }^{18}$ Compare again "Factortame II", supra note 13.
} 
After all, fundamental freedoms attain a much broader scope of protection if they are understood as being a ban on restrictions. ${ }^{19}$ Then they will not only be applicable to regulations discriminating against foreigners but to all kinds of restrictions. Fundamental freedoms will provide protection against regulations which do not distinguish between foreign and domestic citizens of the Member State as well. Therefore they work just like the basic rights of the German Basic Law: ${ }^{20}$ If there is a substantial burden or restriction (encroachment), it will only matter whether the restriction passes the proportionality test or can be justified by opposed interests (compare the freedom of establishment Art. 46 (1) EC).

The development of the fundamental freedoms as discussed above has been already applied by the ECJ in the areas of the freedom of trade and the freedom to provide services. The landmark decision Dassonville 21 applied Art. 28 (1) EC to "all trading rules enacted by Member States which are capable of hindering, directly or indirectly, actually or potentially, intra-community trade" (so called Dassonville formula) which can be seen as the broadest possible definition of all. Thus, the ECJ tried to make two corrections to its adjudication: Certain restrictions were granted to be an exemption from the Dassonville formula in the Keck-Case. ${ }^{22}$ Additionally certain justifications were approved concerning not discriminating regulations applicable in the same way to residents as well as to aliens in Cassis de Dijon. ${ }^{23}$ Still, the ECJ extended the scope of protection of the freedom of trade enormously. A similar development can be recognized as far as the freedom to provide services (Art. 49 ff. EC) is concerned. The important decisions in this field are van Binsbergen ${ }^{24}$ and Säger / Dennemeyer. ${ }^{25}$ Although the ECJ has not yet finally decided upon whether the freedom of establishment has to be interpreted as a ban on restrictions, there are cases like Klopp ${ }^{26}$ who seem to indicate such an interpretation. $^{27}$

But the derivation of a ban on restrictions from the fundamental freedoms has to be called at least questionable. ${ }^{28}$ Due to Art. 43 (1) EC the freedom of establishment is provided for only "within the framework of the provisions set out below" Art. 43 EC. This framework contains especially Art. 43 (2) EC which only provides for a

\footnotetext{
${ }^{19}$ Regarding this, HELMUT LECHELER, EINFÜHRUNG IN DAS EUROPARECHT 264 ff. (2000); MANFRED A. DAUSES, HANDBUCH DES EU-WIRTSCHAFTSRECHTS E.I. n. 61 ff. (1998); HEINZ STREINZ, EUROPARECHT n. 669 ff. ( $\left.5^{\text {th }} \mathrm{ed}, 2001\right)$

${ }^{20}$ Correctly pointed out by Dieter Blumenwitz, Rechtsprobleme im Zusammenhang mit der Angleichung von Rechtsvorschriften auf dem Gebiet des Niederlassungsrechts der freien Berufe - Eine Darstellung anhand einer aktuellen Problematik im Bereich der ärztlichen Heilberufe, 42 NEUE JURISTISCHE WOCHENSCHRIFT 621, 622 (1989).

${ }^{21}$ ECJ, Rec. 1974, 837.

${ }^{22}$ ECJ, Rec. 1993, I-6097.

${ }^{23}$ ECJ, Rec. 1979, 649.

${ }^{24}$ ECJ, Rec. 1979, 1299.

${ }^{25}$ ECJ, Rec. 1991, I-4221.

${ }^{26}$ ECJ, Rec. 1984, 2971.

${ }^{27}$ Blumenwitz, supra note 20, at 623; PIEPER, SCHOLlMEIER \& KRIMPHOVE, supra note 15, at 221; SCHWARZ, supra note 14, at n. 137 ff.; Rolf Wägenbaur, Inhalt und Etappen der Niederlassungsfreiheit, 2 EUROPÄISCHE ZEITSCHRIFT FÜR WIRTSCHAFTSRECHT 427, 431 (1991).

${ }^{28}$ For a well done comprehension of the important arguments see Blumenwitz, supra note 20, at $622 \mathrm{f}$.
} 
right of equality, i.e. the right for a citizen of a foreign Member State not to be treated worse than a domestic citizen. This absolutely non-ambiguous wording distinguishes the freedom of establishment ${ }^{29}$ from the freedom of the movement of capital which does not contain such a restriction (Art. 56 EC: "all restrictions on the movement of capital"). ${ }^{30}$ A European-wide legal harmonization based on Art. 43 EC is therefore impossible. This is especially true due to the fact that Art. 47 (2) EC provides a special authority for such harmonizations. ${ }^{31}$ The ECJ therefore cannot ignore the specifications of the EC. But just like in other areas the ECJ has disregarded the dogmatics in its adjudication. The ECJ is expected to synchronise its adjudication to the individual fundamental freedoms soon and is consequently expected to interpret the freedom of establishment as an extensive ban on restrictions.

The question remains whether one can refer to the freedom of establishment with regard to ones' own Member State. ${ }^{32}$ But the answer to this question is quite obvious when one takes a look at the very wording of Art. 43 (1) (1) EC: It covers only "restrictions on the freedom of establishment of nationals of $a$ Member State in the territory of another Member State". But the ECJ allowed some extensions within this area as well. ${ }^{33}$ So if there is a restriction on the freedom of establishment, it will be examined - comparable to the German Basic Rights dogmatics - whether there is a justification for this restriction. ${ }^{34}$ Such a justification can first of all arise from Art. 46 (1) EC. ${ }^{35}$ But Art. 46 EC is very narrowly worded and is on the other hand also narrowly interpreted by the ECJ. Therefore it leaves no room for the use as a justification of a restriction in most of the cases. Besides that, the general possibility of a restriction which the ECJ developed within Cassis de Dijon ${ }^{36}$ - although regarding the freedom of trade - is applicable to the freedom of establishment. ${ }^{37}$ According to that adjudication, restrictions on both foreign and domestic citizens can be justified by the "general good [...] provided that such application is effected without discrimination". 38 Additionally, the so-called "abusive exercise" adjudica-

\footnotetext{
${ }^{29}$ Compare Art. 3 (2) EC and Art. 50(3) EC.

${ }^{30}$ Streinz, supra note 19 , at n. 667.

${ }^{31}$ Blumenwitz, supra note 20, at 622; Wägenbaur, supra note 27, at 430.

${ }^{32}$ This problem has to be distinguished from the problem whether the freedom of establishment includes a ban on restrictions (correctly pointed out by PETER BEHRENS, PRAXIS DES INTERNATIONALEN PRIVATUND VERFAHRENSRECHTS 354, 360 (1989)). Nonetheless, those problems are connected with each other as Art. 43 EC would not be applicable at all if understood as being just a ban on discriminations.

${ }^{33}$ Compare BEHRENS, supra note 32, at 360; Blumenwitz, supra note 20, at $624 \mathrm{f}$; Ulrich Klinke, Europäisches Unternehmensrecht und EuGH, 23 ZEITSCHRIFT FÜR UNTERNEHMENS- UND GESELLSCHAFTSRECHT 153, 158 ff. (1994).

${ }^{34}$ Compare the graphic description by General Attorney Tesauro in ECJ, Rec. 1998, I-4698 "ICI" para 20.

${ }^{35}$ In detail concerning Art. 46 (2) EC compare Dauses, supra note 19, E. I. at n. $72 \mathrm{ff}$.

${ }^{36}$ Compare supra note 23.

${ }^{37}$ ECJ, Rec. 1977, 765 "Thieffry" para 18. Concerning that case Lecheler, supra note 19, at 244 ff. and 268.

${ }^{38}$ ECJ, Rec. 1988, 2085 "Bond van Adverteerders" para 32.
} 
tion, which the ECJ applies in a wide variety of cases, ${ }^{39}$ may serve as a basis for a justification. $^{40}$

\section{B Company Law}

Company Law is the most important sub area of the European Enterprise Law. In 1985 a new legal form was established that could operate across European borders. This was called the European Economic Interest Grouping (EEIG), regulated within the EEIG council regulation. ${ }^{41}$ Until quite recently the EEIG has been the only original European legal form of a company recognised throughout the EU. The EEIG was created following the French Groupement d'Intérèt Economique in order to enable small and medium-sized enterprises to participate in the Single European Market. But due to its limited applications the EEIG is actually of little practical importance. $^{42}$ It is mainly used for freelance activities as well as for research cooperations; working-groups; and for distribution and advertising organisations.

Therefore, it is even more significant that recently a Statute for a European Company (SE) has finally been established after more than 30 years of quarrels about matters like the involvement of employees and the inclusion of Company Group Law. ${ }^{43}$ Furthermore, there has been a number of proposals for additional European legal forms of companies like the "Amended proposal for a Council Regulation on the Statute for a European Association (EA)"; 4 the "Amended proposal for a Council Regulation on the Statute for a European Cooperative Society (SCE)"; 45 and the "Amended proposal for a Council Regulation on the Statute for a European

\footnotetext{
${ }^{39}$ Regarding the European Enterprise Law compare "Centros" (see supra note 10) para 24; ECJ, Rec. 2000, I-1705; "Diamantis" para 33 - 34 .

${ }^{40}$ But it is no restriction on the general legal execution, like e.g. a ban on improper legal use; regarding this compare "Diamantis" (see supra note 39 ).

${ }^{41}$ Council Regulation (EEC) No $2137 / 85$ of 25 July 1985 on the European Economic Interest Grouping (EEIG) Official Journal L 199, 31/07/1985 p. 1 - 9.

${ }^{42}$ Christoph Graf Von Bernstorff, Das Unternehmensrecht in Europa (Teil I), 9 EUROPÄISCHES WIRTSCHAFTS- UND STEUERRECHT (ZEITSCHRIFT) 397, 400 f. (1998).

${ }^{43}$ Council Regulation (EEC) No 2157/2001 of 8 October, 2001 on the Statute for a European Company (SE), Official Journal L 294, 10/11/2001, 1 ff. and Council Directive 2001/86/EEC of 8 October, 2001 supplementing the Statute for a European Company with regard to the involvement of employees, Official Journal L 294, 10/11/2001, 22 ff. Compare also Peter Hommelhoff, Einige Bemerkungen zur Organisationsverfassung der Europäischen Aktiengesellschaft, 45 DIE AKTIENGESELLSCHAFT (ZEITSCHRIFT) 279, 279 ff. (2001); Andreas Jahn \& Ebba Herfs-Röttgen, Die Europäische AG - Societas Europaea, 54 DER BETRIEB (ZEITSCHRIFT) 631,631 ff. (2001); Andreas Kellerhals \& Dirk Trüten, Neues zur Europäischen Aktiengesellschaft, 97 SCHWEIZERISCHE JURISTEN-ZEITUNG 337, $337 \mathrm{ff}$. (2001); Sorika Pluskat, Die neuen Vorschläge für die Europäische Aktiengesellschaft, 12 EUROPÄISCHE ZEITSCHRIFT FÜR WIRTSCHAFTSRECHT 524, 524 ff. (2001); Peter Wiesner, Der Nizza-Kompromiss zur Europa-AG - Triumph oder Fehlschlag, 22 ZEITSCHRIFT FÜR WIRTSCHAFTSRECHT 397, 397 ff. (2001). Compare also SCHWARZ, supra note 14, at n.1085 ff.

${ }^{44}$ Official Journal C 236, 31/08/1993, 1. The European Association shall mainly include charity associations and charity foundations.

${ }^{45}$ Official Journal C 236, 1993, 17. The European Cooperative Society shall of course mainly include co-operatives. See also the Directive 2003/72/EEC of 22 July, 2003, Official Journal L 207, 2003, 25 and the Regulation (EC) No. 1435/2003 of 22 July, 2003, Official Journal L 207, 2003, 1.
} 
Mutual society (ME)". ${ }^{46}$ The Statute for a European Cooperative Society has already been converted into a Council Regulation in July 2003 and shall be applied from August 2006 onwards. Thus, it will be apparent that there were several attempts in the EU to establish legal forms that can conduct business across European borders and without the necessity to adhere to the company law regulations of a particular EU State.

So far the original European legal forms of companies have only been of secondary importance which eventually results in a questionable significance of the Directives. Moreover, there are obvious differences between Directives which are already in force and on the other hand mere proposals for Council Regulations. A key directive within Company Law is the "share capital" Directive, ${ }^{47}$ which includes regulations about the capital maintenance and alteration of public limited companies. There are a number of other important Directives within the area of Company Law. On the one hand the "disclosure" Directive ${ }^{48}$ imposes significant regulations regarding compulsory disclosure requirements for specific forms of companies like the German Aktiengesellschaft (stock option corporation or German public limited corporation), Kommanditgesellschaft auf Aktien (commercial partnership limited by shares) and Gesellschaft mit beschränkter Haftung (limited liability company). On the other hand there is the so-called "structure" Directive which includes detailed regulations concerning the structure of public limited companies. ${ }^{49}$ However, this Directive is not in force yet but remains in the legislative process as a proposal for a Council Directive. Worth mentioning for having a bearing on Company Law are also the Articles $1-2,4$ et seqq. of the Twelfth Council Company Law Directive on single-member private limited-liability companies ${ }^{50}$ and the planned proposal for

\footnotetext{
${ }^{46}$ Official Journal C 236, 1993, 40. The European Provident Mutual Society is especially designed for cross-border mutual activities concerning precautions and insurances.

${ }^{47}$ Second Council Directive 77/91/EEC of 13 December, 1976 on coordination of safeguards which, for the protection of the interests of members and others, are required by Member States of companies within the meaning of the second paragraph of Article 58 of the Treaty, in respect of the formation of public limited liability companies and the maintenance and alteration of their capital, with a view to making such safeguards equivalent, Official Journal L 026, 31/01/1977, 1 - 13; amended by the Council Directive 92/101/EEC of 23 November, 1992 amending Directive 77/91/EEC on the formation of public limited-liability companies and the maintenance and alteration of their capital, Official Journal L 347, 28/11/1992, 64 - 66.

${ }^{48}$ First Council Directive 68/151/EEC of 9 March, 1968 on co-ordination of safeguards which, for the protection of the interests of members and others, are required by Member States of companies within the meaning of the second paragraph of Article 58 of the Treaty, with a view to making such safeguards equivalent throughout the Community, Official Journal L 65, 14/03/1968, 8 - 12.

${ }^{49}$ Third Amendment to the proposal for a Fifth Council Directive based on Article 54 of the Treaty concerning the structure of public limited companies and the power and obligations of their organs, Official Journal, C 321, 20/11/1991, 9 ff. In detail concerning the "structure" Directive compare Schwarz, supra note 14, at n. 705 ff. with additional references just ahead of n. 705 .

${ }^{50}$ Twelfth Council Company Law Directive 89/667/EEC of 21 December, 1989 on single-member private limited liability companies, Official Journal L 395, 30/12/1989, 40 ff. Compare also HansWerner Eckert, Die Harmonisierung des Rechts der Einpersonen-GmbH, 1 EUROPÄISCHE ZEITSCHRIFT FÜR WIRTSCHAFTSRECHT 54, 54 ff. (1990); Marcus Lutter, Mißglückte Rechtsangleichung: das Chaos der Ein-Personen-Gesellschaft in Europa, in FESTSCHRIFT FÜR HANS-ERICH BRANDNER 81, $81 \mathrm{ff}$. (1996); Hans-Christoph Schimmelpfennig \& Christoph E. Hauschka, Die Zulassung der Ein-PersonenGmbH in Europa und die Änderungen des deutschen GmbH-Rechts, 45 NEUE JURISTISCHE WOCHENSCHRIFT 942, 942 ff. (1992).
} 
a $14^{\text {th }}$ Company Law Directive on the cross-border transfer of the registered office of limited companies.

\section{Corporate Transformation Law, Takeover Law and Company Group Law.}

The Corporate Transformation Law, Takeover Law and Company Group Law are naturally closely related to Company Law in general. At the European level rules on corporate transformations can be found in the "mergers" Directive ${ }^{51}$ and in the "divisions" Directive. ${ }^{52}$ Worth mentioning as well is the proposal for a "crossborder mergers" Directive ${ }^{53}$ which remains in the legislative process though.

But this whole field of law generally remains subject to fierce discussions. A good example of that may be the "takeover" Directive. It has been vehemently discussed within past decades ${ }^{54}$ and its amended proposal for a Company Law Directive ${ }^{55}$ has been turned down by the European Parliament in its third and crucial reading on July $4^{\text {th }}, 2001$. Surprisingly, a breakthrough has been reached more than two years afterwards in late 2003. ${ }^{56}$ In contrast, the Ninth Company Group Law Directive might not have the slightest prospects of being approved and is even considered to be "dead" by some legal writers. ${ }^{57}$ Moreover, German legal writers are also very sceptical whether the Directive on single-member private limited-liability companies ${ }^{58}$ includes any aspects of Company Group Law at all. ${ }^{59}$ It is quite significant

\footnotetext{
${ }^{51}$ Third Council Directive 78/855/EEC of 9 October, 1978 based on Article 54 (3) (g) of the Treaty concerning mergers of public limited liability companies, Official Journal L 295, 20/10/1978, $36 \mathrm{ff}$. (Third Council Company Law Directive, so-called "mergers" Directive).

${ }^{52}$ Sixth Council Directive 82/891/EEC of 17 December, 1982 based on Article 54 (3) (g) of the Treaty, concerning the division of public limited liability companies, Official Journal L 378, 31/12/1982, $47 \mathrm{ff}$. (Sixth Council Company Law Directive, so-called “divisions” Directive).

${ }^{53}$ Proposal for a Tenth Directive of the Council based on Article 54 (3) (g) of the Treaty concerning cross-border mergers of public limited companies, Official Journal C 23, 25/01/1985, 11.

${ }^{54}$ Compare for instance Karsten Munscheck, Der Vorschlag zur EG-Übernahmerichtlinie, 41 RECHT DER INTERNATIONALEN WIRTSCHAFT 388, 388 ff. (1995); Gunnar Schuster, Der neue Vorschlag für eine EG-Takeover-Richtlinie und seine Auswirkungen auf den Übernahmekodex, 8 EUROPÄISCHE ZEITSCHRIFT FÜR WIRTSCHAFTSRECHT 237, 237 ff. (1997); Martin Weber, Der geänderte Vorschlag der Kommission für eine Takeover-Richtlinie vom 10.11.1997, 9 EUROPÄISCHE ZEITSCHRIFT FÜR WIRTSCHAFTSRECHT 464, 464 ff. (1998); Carl-Heinz Witt, Der neue Vorschlag für eine EG-Richtlinie über Übernahmeangebote, 9 EUROPÄISCHES WIRTSCHAFTS- UND STEUERRECHT (ZEITSCHRIFT) 318, 318 ff. (1998).

55 Amended proposal for a thirteenth European Parliament and Council Directive on company law concerning takeover bids, Official Journal C 378, 13/12/1997, 10.

${ }^{56}$ Compare Part E.

${ }^{57}$ Klaus J. Hopt, Europäisches Konzernrecht?, 10 EUROPÄISCHE ZEITSCHRIFT FÜR WIRTSCHAFTSRECHT 577, 577 ff. (1999).

${ }^{58}$ See supra note 50.

59 Compare Tim Drygala, Konzernhaftung und Einmann-Richtlinie, 13 ZEITSCHRIFT FÜR WIRTSCHAFTSRECHT 1528, 1528 ff. (1992); Heribert Hirte, Die Zwölfte EG-Richtlinie als Baustein eines Europäischen Konzernrechts?, 13 ZEITSCHRIFT FÜR WIRTSCHAFTSRECHT 1122, 1122 ff. (1992); Peter Kindler, Gemeinschaftsrechtliche Grenzen der Konzernhaftung in der Einmann-GmbH, 157 ZEITSCHRIFT FÜR DAS GESAMTE HANDELS- UND WIRTSCHAFTSRECHT 1, 1 ff. (1993); Wienand Meilicke, Unvereinbarkeit der Video-Rechtsprechung mit EG-Recht, 45 DER BETRIEB (ZEITSCHRIFT) 1867, 1867 ff. (1992); Hans-Werner Neye, Die Video-Rechtsprechung und das EG-Recht, DEUTSCHE
} 
though that the new Regulation on the control of concentrations between undertakings ("EC Merger Regulation") has finally been implemented in April 2004 and brought along some important changes. As regards the basic criterion for analysing mergers, the Regulation determines the "substantial lessening of competition" criterion used in other jurisdictions - e.g. in the United States and Australia - as the new basic criterion replacing the former "dominant position" criterion that had been used up to that point.

\section{Accounting Regulations}

The European Accounting Directives include very detailed rules for the national jurisdictions of the Member States. On the one hand it consists of the Fourth Council Directive on the annual accounts ${ }^{60}$ which is also called the "accounts" Directive and which was amended particularly by the "SME" Directive ${ }^{61}$ and another Council Directive on consolidated accounts regarding the scope of the former Directives. ${ }^{62}$ On the other hand the European Accounting Directives include the Seventh Council Company Law Directive on consolidated accounts ${ }^{63}$ and the Eighth Council Company Law Directive on auditors. ${ }^{64}$ For each financial year starting on or after January $1^{\text {st }}, 2005$, Member States may permit or require companies governed by their law according to Art. 5 of the IAS regulation ${ }^{65}$ to prepare their consolidated accounts in conformity with the international accounting standards as defined in Art. 2 of the IAS regulation. An easing of rules for small and medium-sized companies is included in the "SME" Directive ${ }^{66}$ and another Council Directive ${ }^{67}$ includes the

ZEITSCHRIFT FÜR WIRTSCHAFTSRECHT 452, 452 ff. (1992); Wulf-Henning Roth, ,,Video“-Nachlese und das (immer noch) vergessene Gemeinschaftsrecht, 13 ZEITSCHRIFT FÜR WIRTSCHAFTSRECHT 1054, 1054 ff. (1992); Matthias Schüppen, Haftung im qualifiziert faktischen GmbH-Konzern und 12. EGRichtlinie, DER BETRIEB (ZEITSCHRIFT) 969, 969 ff. (1993); Hans-Detlef Schwarz, GmbH-Konzernrecht und Europäisches Gemeinschaftsrecht, INTERNATIONALES STEUERRECHT 23, 23 ff. (1993); Ulrich B. Wilhelm, Haftung im qualifiziert-faktischen Konzern und Europarecht 4 EUROPÄISCHE ZEITSCHRIFT FÜR WIRTSCHAFTSRECHT 729, 729 ff. (1993).

${ }^{60}$ Fourth Council Directive 78/660/EEC of 25 July, 1978 based on Article 54 (3) (g) of the Treaty on the annual accounts of certain types of companies, Official Journal L 222, 14/08/1978, $11 \mathrm{ff}$. (Fourth Council Company Law Directive).

${ }^{61}$ Council Directive 90/604/EEC of 8 November, 1990 amending Directive 78/660/EEC on annual accounts and Directive 83/349/EEC on consolidated accounts as concerns the exemptions for small and medium-sized companies and the publication of accounts in ecus, Official Journal L 317, 16/11/1990, 57 ff.

${ }^{62}$ Council Directive 90/605/EEC of 8 November, 1990 amending Directive 78/660/EEC of annual accounts and Directive 83/349/EEC on consolidated accounts as regards the scope of those Directives, Official Journal L 317, 16/11/1990, $60 \mathrm{ff}$.

${ }^{63}$ Seventh Council Directive 83/349/EEC of 13 June, 1983 based on the Article 54 (3) (g) of the Treaty on consolidated accounts, Official Journal L 193, 18/07/1983, 1 ff. (Seventh Council Company Law Directive).

${ }^{64}$ Eighth Council Directive 84/253/EEC of 10 April 1984 based on Article 54 (3) (g) of the Treaty on the approval of persons responsible for carrying out the statutory audits of accounting documents, Official Journal L 126, 12/05/1984, 20 ff. (Eighth Council Company Law Directive).

${ }^{65}$ Regulation (EC) No 1606/2002 of the European Parliament and of the Council of 19 July, 2002 on the application of international accounting standards, Official Journal L 243, 11/09/2002, $1 \mathrm{ff}$.

${ }_{66}$ Council Directive 90/604/EEC of 8 November, 1990 amending Directive 78/660/EEC on annual accounts and Directive 83/349/EEC on consolidated accounts as concerns the exemptions for small and 
German legal form of a $G m b H \& C o . K G$ into the scope of the "accounts" Directive. There are also some Commission Recommendations worth mentioning. They are the Commission Recommendation of November $15^{\text {th }}, 2000$ on the quality assurance for the statutory audit; ${ }^{68}$ the Commission Recommendation of May $30^{\text {th }}, 2001$ on environmental issues in the annual accounts; ${ }^{69}$ and the Commission Recommendation of May $16^{\text {th }}, 2002$ on the statutory auditors' independence in the EU. ${ }^{70}$

\section{E Disclosure}

The disclosure requirements are closely related to accounting regulations and can therefore be regarded as being a legal sub-area of European Enterprise Law. The requirements are contained within the first section of the "disclosure" Directive, ${ }^{71}$ within the Council Directive on disclosure requirements in respect of company branches ${ }^{72}$ and also within the tenth section of the "accounts" Directive. ${ }^{73}$ Finally an amendment to the Directive 68/151/EEC was proposed with regards to disclosure requirements in respect of certain types of companies. ${ }^{74}$

\section{F Antitrust Law}

The European Antitrust Law established itself as a separate and widely recognized branch of law within the general European Enterprise Law. Statutory basis for Antitrust Laws are included both within the Art. 81 et seqq. EC and within various Regulations like the Merger Regulation and the Block Exemption Regulations.

\section{G Tax Law}

The European Tax Law has long since concentrated on indirect taxation. This was caused by Art. $93 \mathrm{EC}$, which only provides a specific legal foundation for indirect taxation. Several Directives concerning indirect taxation had already been issued at a very early stage of the EU. In the meantime several Directives have been issued

medium-sized companies and the publication of accounts in ecus, Official Journal L 317, 16/11/1990, 57 ff.

${ }^{67}$ Council Directive 90/605/EEC of 8 November, 1990 amending Directive 78/660/EEC of annual accounts and Directive 83/349/EEC on consolidated accounts as regards the scope of those Directives, Official Journal L 317, 16/11/1990 60 ff.

${ }^{68}$ Commission Recommendation of 15 November, 2000 on quality assurance for the statutory audit in the European Union: minimum requirements, Official Journal L 91, 31/03/2001, $91 \mathrm{ff}$.

${ }^{69}$ Commission Recommendation of 30 May, 2001 on the recognition, measurement and disclosure of environmental issues in the annual accounts and annual reports of companies, Official Journal L 156, 13/06/2001, $33 \mathrm{ff}$.

${ }^{70}$ Commission Recommendation of 16 May, 2002 - Statutory Auditors' Independence in the EU: A Set of Fundamental Principles, Official Journal L 191, 19/07/2002, 22 ff.

${ }^{71}$ Compare supra note 48.

${ }^{72}$ Eleventh Council Directive 89/666/EEC of 21 December, 1989 concerning disclosure requirements in respect of branches opened in a Member State by certain types of company governed by the law of another State, Official Journal L 395, 30/12/1989, 36 ff. (Eleventh Council Company Law Directive).

${ }^{73}$ Compare supra note 60.

${ }^{74}$ KOM (2002) 279 endg., Official Journal C 227, 24/09/2002, 377 ff. 
amongst all Member States aimed at a legal harmonization of indirect taxation especially with regards to turnover tax and excise duties. ${ }^{75}$ In contrast, the only legal foundation for a legal harmonization of direct taxation among the Member States is the most general legal foundation of Art. 94 EC, which concerns all kinds of legal harmonizations. Therefore, legal harmonization of direct taxation based on this particular legal foundation is an especially difficult issue and has not progressed well so far due to Art. 94 EC requiring unanimity. Those difficulties led to the delay of some directives like the "taxation of mergers" Directive ${ }^{76}$ and the "parent and subsidiary" Directive ${ }^{77}$ which did not go into force until 1990.

\section{H Capital Markets Law}

The Capital Markets Law may be considered to be a „cross-sectional law“. The position as a "cross-sectional law" derives from the entirety of laws which are summarized within the term of capital markets law. Those laws naturally cover all activities on any capital markets in general and include in particular e. g. the law on securities; banking law; stock exchange rules; and investment laws. Therefore there are also many sources of law at a European level like the "insider dealing" Directive $^{78}$ and the "investment services" Directive ${ }^{79}$.

It will be apparent from the discussion above that the European Enterprise Law can be characterised as a densely regulated area of European law. Although at the very beginning the European Enterprise Law was nothing more than a small string linking different fields of law, it developed over time to a tightly knit network of laws. The legal harmonization of this field of law however did not keep pace with this development unlike the harmonization in other branches of law like e.g. consumer protection. But it remains noteworthy that the process of legal harmonization did indeed gather considerable momentum in recent years.

\footnotetext{
${ }^{75}$ In detail Wolfram Birkenfeld, Der Einfluss des Gemeinschaftsrecht auf die Rechtsverwirklichung im Steuerrecht - Eine Bestandsaufnahme, 75 STEUER UND WIRTSCHAFT (ZEITSCHRIFT) 55, 57 f. (1998) with further bibliography.

${ }^{76}$ Council Directive 90/434/EEC of 23 July, 1990 on the common system of taxation applicable to mergers, divisions, transfer of assets and exchanges of shares concerning companies of different Member States, Official Journal L 225, 20/08/1990, 1 ff. For an overview compare Brigitte Knobbe-Keuk, Die beiden Unternehmenssteuerrichtlinien, 3 EUROPÄISCHE ZEITSCHRIFT FÜR WIRTSCHAFTSRECHT 336, 341 ff. (1992).

${ }^{77}$ Council Directive 90/435/EEC of 23 July, 1990 on the common system of taxation applicable in the case of parent companies and subsidiaries of different Member States, Official Journal L 225, 20/08/1990, 6 ff. Compare for an introduction Knobbe-Keuk, supra note 76, at $337 \mathrm{ff}$.

${ }^{78}$ Council Directive 89/592/EEC of 13 November, 1989 coordinating regulations on insider dealing, Official Journal L 334, 18/11/1989, $30 \mathrm{ff}$.

${ }^{79}$ Council Directive 93/22/EEC of 10 May, 1993 on investment services in the securities field, Official Journal L 141, 11/06/1993, 27 ff.
} 


\section{FreEdom OF ESTABLISHMENT}

The general importance of the freedom of establishment as a European fundamental freedom has already been pointed out before. ${ }^{80}$ The freedom of establishment plays an especially important role concerning the transfer of a company's seat and crossborder mergers of companies. But beyond all controversial questions which may arise at first glance there even exists a deeply rooted dispute about a conflict of law. The matter in dispute is the determination of the company agreement and the subsequent question whether this is determined according to the incorporation doctrine or according to the real seat doctrine. One of the eminent questions is whether a company with an ongoing operational business in one Member State can legally claim to have its real seat in another Member State. Another controversial aspect concerns the question, whether it is possible to enforce certain foreign regulations in the Member State in which the company currently holds its seat to ensure certain legal requirements which do only exist in the foreign Member State where the company was once incorporated. When it comes to comparing the two relevant doctrines, aspects of clearer rules and steadiness imply a preference for the incorporation doctrine. In contrast, the real seat doctrine clearly favours national conservation interests of the Member States regarding issues like e. g. the involvement of employees; capital formation and maintenance; and directors' liability. Daily Mail $^{81}$ was once interpreted to be a sign for the preference of the real seat doctrine. It was a questionable sign though as the case did not concern the taking up residence but the actual departure. Consequently Centros $^{82}$ can be seen as the turning point in favour of the incorporation doctrine, which was further strengthened by the now famous $\ddot{\text { Uberseering }}{ }^{83}$ and Inspire Art ${ }^{84}$ cases.

The recognition of the incorporation doctrine in cases of taking-up residence therefore eliminates a restriction on the taking-up residence of companies which were incorporated within the EU. This will lead to a competition among the legal systems of the European Member States especially with regards to the individual company laws. A good example of the fierce competition are the preliminary and formation expenses of the British Limited which amount to just $1 £$ (about $1.5 €$ ) whilst even requiring only the most minor protection of creditors and shareholders at all. Yet another example is the advantages which the French legal form of a so called "blitz"-Société à responsabilité limitée (SARL; limited private partnership) bears in itself, which is on the one hand the incredibly fast incorporation and on the other

\footnotetext{
${ }^{80}$ Compare Part B. I.

${ }^{81}$ ECJ, Judgment of 27 September, 1988 - Case 81/87, Rec. 1988, 5483.

${ }^{82}$ ECJ, Judgment of 9 March, 1999 - Case C-212/97, Rec. 1999, I-1459.

${ }^{83}$ ECJ, Judgment of 5 November, 2002 - Case C-208/00, Rec. 2002, I-9919.

${ }^{84}$ ECJ, Judgment of 30 September, 2003 - Case C-167/01, 14 EUROPÄISCHE ZEITSCHRIFT FÜR WIRTSCHAFTSRECHT 687, $687 \mathrm{ff} .(2003)=56$ NEUE JURISTISCHE WOCHENSCHRIFT 3331, $3331 \mathrm{f}$. (2003). Compare also Otto Sandrock, BB-Forum - Nach Inspire Art - Was bleibt vom deutschen Sitzrecht übrig?, 58 BETRIEBSBERATER (ZEITSCHRIFT) 2588, $2588 \mathrm{ff}$. (2003), and especially concerning the "overlay doctrine" Otto Sandrock, Die Schrumpfung der Überlagerungstheorie, 102 ZEITSCHRIFT FÜR VERGLEICHENDE RECHTSWISSENSCHAFT 447, 447 (2003) as well as Walter Bayer, Die EuGHEntscheidung Inspire Art und die deutsche GmbH im Wettbewerb der europäischen Rechtsordnungen, 58 BETRIEBSBERATER (ZEITSCHRIFT) 2357, 2357 ff. (2003).
} 
hand the determination of the minimum capital by the partners themselves. For all of those reasons the appearance of pseudo-offshore-companies is to be expected. In the future the differences in approach among the various European Member States regarding the requirements for incorporation and protection mechanisms to ensure that the limited liability company is not abused will become more and more important. The German system provides for two specific mechanisms to ensure that the privilege of incorporation and limited liability are not abused. First, the German has stricter requirements to control incorporation. Secondly, the German system also has strict principles for capital formation and maintenance. The so-called "British system" on the other hand is based on a Directors \& Officers (D\&O) liability; extensive disclosure requirements; and a strict insolvency law.

However, there are serious issues regarding compatibility involved in the two systems, not even to mention the other alternative company law arrangements in the EU. It may lead to serious difficulties if all the less restrictive arrangement of all EU States will apply. For example, in view of the real seats theory, can a company incorporate under the British system with its lesser requirements for incorporation and capital maintenance, but insist that the less stringent German arrangements regarding the liability of directors and officers apply? This could easily lead to a type of a "race to the bottom" in the EU context — the concept that all corporations would like to incorporate in the European Members state where there are the least stringent requirements for incorporation and also the least stringent requirements for the liability of directors and officers.

In contrast to the aspects of taking up residence, the legitimacy of restrictions on the departure of companies remains absolutely unclear in light of the Daily Mail decision. This issue concerns regulations which a Member State imposes upon companies which incorporated themselves within this Member State and which revoke the legal capacity of a company once it transfers its real seat to another Member State. Due to reasons like the protection of creditors; minority shareholders; controlled companies; fiscal authorities; and their right to impose taxes, the general possibility of the use of domestic law and the limitations on its exceptional use have to be considered as well.

Finally, yet another issue remains about the legitimacy of restrictions on the freedom of establishment to protect the participation rights of employees. Accordingly several essential aspects of the European Company Law have yet to be solved and a further on vivid discussion about the legal issues at stake is necessary. Therefore one can speak of an urgent call for action on a further legal harmonization. 


\section{FORMS OF EUROPEAN COMPANIES}

The existing forms of European Companies were already mentioned before. ${ }^{85}$ They are the European Economic Interest Grouping (EEIG) and the Societas Europaea (SE). The EEIG ${ }^{86}$ cannot be called a fully adequate form of a company though as it does not intend to realize its profits but is only allowed to act as a cooperative union of its members to serve their economic interests by auxiliary activities. Currently there are about 1,400 registered EEIGs within the EU of which 362 operate in Belgium, 243 in France, 163 in Great Britain and finally 143 in Germany.

The SE on the other hand seems to be quite a bit of a political compromise. The most obvious fact supporting this conclusion is the existence of two regulations on the topic of the SE, a Council Regulation ${ }^{87}$ and another Council Directive ${ }^{88}$ with special regard to the involvement of employees. The earliest proposals for the SE can be traced back to the years $1970,1975,1989$ and 1991. The political compromise though was not made until the EU talks at Nice in December 2000. There are two important aspects within the establishment regulations of the SE which prove its cross-border existence. First there is a possibility of a cross-border transfer of the company's seat (via a transfer proposal) without the need to dissolve the company or to establish a new company. But there is also the choice between a unitary and a two-tier board structure. The involvement of employees has been established in a more complex way though. First of all the different bodies and the employees have to agree on a model of participation. But if an agreement cannot be reached, a set of standard principles will stand in for an agreement and will be as strict as the strictest model of participation which exists among any of the companies involved in the incorporation.

Although the SE came into existence in October 2004 as a legal body with a minimum share capital of $120,000 €$, it remains to be seen how popular the SE will be and how it will develop further. One thing is certain, because of the possibility that different types of SE could be incorporated as provided for in the EU provisions that enable the establishment of SEs, many different forms of SEs are likely to occur even within a single Member States. Therefore the aim of simplification of Company Law within the EU can only to a certain extent be reached with the Statute of the European Public Company. In the long run those Member State models are likely to succeed which pay the greatest attention to entrepreneurial aspects. Thus it will probably lead to a competition of the different models and not to a harmonization of law at all. This legal form of a company may even be a great disadvantage for German companies and may isolate them from the rest of Europe.

\footnotetext{
${ }^{85}$ Compare Part B. II.

${ }^{86}$ Council Regulation (EEC) No 2137/85 of 25 July, 1985 on the European Economic Interest Grouping (EEIG) Official Journal L 199, 31/07/1985, $1 \mathrm{ff}$.

${ }^{87}$ Council Regulation (EEC) No 2157/2001 of 8 October, 2001 on the Statute for a European Company (SE), Official Journal L 294, 10/11/2001, p. $1 \mathrm{ff}$.

${ }^{88}$ Council Directive 2001/86/EEC of 8 October, 2001 supplementing the Statute for a European Company with regard to the involvement of employees, Official Journal L 294, 10/11/2001, 22 ff.
} 
As this legal form is especially supposed to be applied to cross-border mergers, companies will try to avoid the typically extensive German form of employees' participation at all costs and will avoid merging with German companies as they would have to adopt the German models of employee participation. After the incorporation doctrine has been established, ${ }^{89}$ the legal form of the SE becomes especially questionable with regard to the possibility of a transfer of the company's seat and only time will tell how important the SE will be after all.

\section{TAKEOVER LAW}

Let us now deal with the most central aspect of mergers and acquisitions, Takeover Law. Takeover Law goes back in history for more than 30 years now. First of all, Takeover Law aims at creating a Level playing Field and thus aims at a rearrangement of the European economy and at an improvement of the international competitiveness of European Companies. It therefore uses the several means of a harmonization of Takeover Law to achieve a Level Playing Field, including encouragement of company restructuring; stability of the law during takeovers; protection of minority shareholders; and counter-measures against takeovers. Efforts to create a single European Takeover Law $^{90}$ had already been undertaken for decades when the European Parliament decided on July $4^{\text {th }}, 2001$ to temporarily dismiss the whole issue. A year afterwards though, the European Parliament initiated a proposal for a Directive on takeover bids ${ }^{91}$ on October $2^{\text {nd }}, 2002$ and put the proposal forward as part of the co-decision procedure. ${ }^{92}$ The Directive, put into force in April 2004, still constitutes nothing more than a compromise and therefore can only be regarded as a minimum solution. ${ }^{93}$ This is especially true as the existing structures

\footnotetext{
${ }^{89}$ See Part C.

${ }^{90}$ Regarding the development of European Takeover Law see for an overview Alexander Zinser, Entwicklungen zu einem europäischen Übernahmerecht, 36 Zeitschrift für Rechtspolitik 78, $78 \mathrm{ff}$. (2003),

${ }^{91}$ Proposal for a Directive of the European Parliament and of the Council on takeover bids, Official Journal C 45 E, 25/02/2003, 1 ff.; printed as well in 57 ZEITSCHRIFT FÜR WIRTSCHAFTSRECHT 1863, $1863 \mathrm{ff}$. (2002). See also the report from BARBARA DAUNER-LIEB \& MARCO LAMANDINI (REPORT TO THE EUROPEAN PARLIAMENT ON THE COMMISSION'S NEW PROPOSAL OF A DIRECTIVE ON COMPANY LAW CONCERNING TAKEOVER BIDS, WITH PARTICULAR REFERENCE TO THE RECOMMENDATIONS OF THE HIGH LEVEL GROUP OF COMPANY LAW EXPERTS SET UP BY THE EUROPEAN COMMISSION AND TO THE ACHIEVEMENT OF A LEVEL PLAYING FIELD IN THE DOMAIN OF TAKEOVER BIDS, Study no. IV/2002/06/01) and regarding that compare also Barbara Dauner-Lieb \& Marco Lamandini, Der neue Kommissionsvorschlag einer EU-Übernahmerichtlinie - Stellungnahme der Gutachter des EUParlaments, 58 BETRIEBSBERATER (ZEITSCHRIFT) 265, 265 ff. (2003).

${ }^{92}$ This proposal is based on the results from the Winter group, a High Level Group of Company Law Experts, see <http://europa.eu.int/comm/internal_market/en/company/company/news/02-24.htm>.

${ }^{93}$ Directive 2004/25/EEC of the European Parliament and of the Council of 21 April, 2004 on takeover bids, Official Journal L 142, 30/04/2004, 12 ff.
} 
within Company Law remain intact and the only adjustment factors are market forces and the competition of the different legal systems. ${ }^{94}$

The European Takeover Code is generally based on the principle of neutrality among the members of the board of the offeree company in case of a hostile bid. Therefore the Takeover Code abandons defensive measures like multiple voting rights and limitations on voting rights but exceptionally grants Member States the option to hold on to some defensive measures. However, the Takeover Code grants general meetings the authority to either dismiss this option and accept the Takeover Code or to accept the option yet again after it has been dismissed once by a shareholders' resolution. Having said that, some serious problems may arise in Germany as Germany already abolished the multiple voting rights in an attempt to anticipate future developments (an example of 'hurried obedience') and by doing this the principle of neutrality was more or less destroyed. Ultimately, the framework of the Takeover Code becomes less clear and the use of defensive measures is left to the individual company's discretion. In conclusion it has to be put on record that the compromise on the European Takeover Law is as a matter of fact anything but a compromise and can only be regarded as a collective of the interests of the individual Member States which does not set a good example on the harmonization of law at all.

\section{VI \\ Action Plan on "Modernising Company LAW AND ENHANCING CORPORATE GOVERNANCE IN THE EU” PRESENTED BY THE EUROPEAN COMMISSION ON MAY 21 ${ }^{\mathrm{ST}}, 2003$}

In the European Union, the set of rules for Corporate Governance is not only formed by acts governing a company's formation, operation and termination. More and more, Codes of Corporate Governance become more prominent, especially since almost fifty codes of Corporate Governance exist in Europe. Many of these codes are based on a "comply or explain"-approach, i.e. listed companies are invited to disclose whether they comply with the code and to explain any deviations. The addressees of the codes are often required to specify annually the principles with which they have complied and explain the extent of and the reasons for any material non-compliance.

The added value of the Corporate Governance Codes is that they bring an end to the uncontrolled growth of numerous private recommendations. Thus, the Codes con-

\footnotetext{
${ }^{94}$ Regarding the correlation with the Art. 1 of the German Gesetz zur Regelung von öffentlichen Angeboten zum Erwerb von Wertpapieren und von Unternehmensübernahmen (WpÜG) of 20 December, 2001, BGB1. I, S. 3822, compare for instance Ingo Saenger, Tendenzen im europäischen Übernahmerecht: Die Vereinbarkeit des deutschen WpÜG mit dem Richtlinienvorschlag vom 2. 10. 2002, in RECHTSVERGLEICHUNG ALS ZUKUNFTSTRÄCHTIGE AUFGABE - MÜNSTER STUDIES IN COMPARATIVE LAw (Otto Sandrock et. al. eds., Volume 100, 2004).
} 
tribute to legal certainty. Besides, a Corporate Governance Code provides transparency of domestic corporate laws which is especially important for foreign investors.

But, on the one hand, the high number of codes which may lead to confusion and which possesses potential conflicts, might be a reason for a European "SuperCode". On the other hand, it can be doubted if an additional code will solve these problems. In general, it can be questioned how far the structures of European Corporate Law can be harmonized at all, since a unitary corporate model does not exist and each domestic regulation has its own identity. Among other reasons, the intention of the European Commission is not, as it has repeatedly been stressed, to produce a European Corporate Governance Code. Instead of implementing an additional Code, the Commission confines itself to give Recommendations. Unlike other initiatives taken at EU level in the area of company law which are based on Article 44 (2) $\mathrm{g}$ of the EC Treaty, the legal basis for the recommendation is Article 211 of the EC Treaty, which gives the Commission power to formulate recommendations on matters dealt with in the EC Treaty. Moreover, also in contrast with domestic Corporate Governance Codes, the Recommendation is not designated for direct use by listed companies, but it addresses member states which should be free when implementing the Recommendation to decide to introduce in their national framework binding provisions where appropriate. Nevertheless, due to the practical effect of the Recommendation to curtail companies' flexibility to adopt its own board structure, the current Recommendation on the role of independent nonexecutive or supervisory directors was criticized and finally several compromises were reached on the strict requirements for independence. It should be appreciated that it will almost be impossible for German public companies to comply with a strict requirement of having a majority of independent non-executive directors because there are employee representatives sitting on the supervisory boards of many listed corporations and because there are often representatives from the banks serving on the supervisory boards of many large German corporations. ${ }^{95}$ Hence, on the background of numerous domestic Corporate Governance codes and bearing the European pluralism of interests in mind, it will be interesting to watch the future acceptance and effect of the Recommendation.

In recent years though, European Company and Business Law has advanced quite a few steps. The proposals made within the Action Plan on "Modernising Company Law and Enhancing Corporate Governance in the EU" presented by the European Commission on May 21 ${ }^{\text {st }}, 2003$ actually derive from the report of the High Level Group of Company Law Experts (so-called "Winter group") on a Modern Regulatory Framework for Company Law in Europe which was published in November 2002. ${ }^{96}$ The European Commission published the Action Plan on the same day as

\footnotetext{
${ }^{95}$ Klaus J Hopt, Modern Company and Capital Market Problems: Improving European Corporate Governance After Enron, 3 JOURNAL OF CORPORATE LAW STUdIES 221, 237-238 (2003). See also Jean J du Plessis, The German Two-Tier Board and the German Corporate Governance Code, 15 EUROPEAN B.L REV. 1139, 1151 (2004).

${ }^{96}$ Compare Silja Maul, Erich Eggenhofer \& Georg Lanfermann, Aktionsplan der Europäischen Kommission zur Reform des Europäischen Gesellschaftsrechts, 58 BETRIEBSBERATER (ZEITSCHRIFT) 1289, 1289 ff. (2003). Regarding the report of the Winter group see Peter Wiesner, Neue Brüsseler
} 
the proposal for ten priorities on the audit of company accounts. The Action Plan is prioritised over the short term $(2003$ - 2005), medium-term $(2006$ - 2008) and long-term (2009 onwards), and indicates which type of regulatory instrument should be used for each proposal, with approximate timescales. The regulatory instruments include non- binding recommendations as well as specific directives. The main objectives of the Action Plan are to harmonize corporate governance rules; to strengthen shareholders' rights and protection for employees; and to foster the efficiency and competitiveness of business with special attention to some specific cross-border issues. Former Internal Market Commissioner Frits Bolkestein said with regard to the Action Plan that "economies only work if companies are run efficiently and transparently" which is the very reason why the EC has "to be a model for the rest of the world". 97

Short-term recommendations $(2003$ - 2005) are to improve the EU framework for corporate governance, specifically through:

- enhanced corporate governance disclosure requirements;

- an integrated legal framework to facilitate efficient shareholder information, communication and decision-making, on a cross-border basis, using where possible modern technology;

- modernisation of company boards, specifically through

$\circ \quad$ strengthening the role of independent non-executive and supervisory directors;

- an appropriate regime for directors' remuneration;

- confirming as a matter of EU law the collective responsibility of board members for the company's financial and key non-financial statements;

- $\quad$ setting up a structure to co-ordinate the corporate governance efforts of Member States.

The annual corporate governance statement should at least include the following key items:
- the operation of the shareholders meeting and its key powers;
- the rights attached to shares and how these rights can be executed;
$\circ \quad$ the operation of the board and its committees and the procedure for the appointment of board members;
○ the shareholders holding major shareholdings and their voting and control rights;
○ the other direct and indirect relationships with the major sharehold- ers;
- transactions with other parties;
$\circ \quad$ existence and nature of a risk management system and
$\circ \quad$ a reference to a national code of corporate governance.

Impulse für Corporate Governance und Gesellschaftsrecht, 58 BETRIEBSBERATER (ZEITSCHRIFT) 213, 213 ff. (2003).

${ }^{97}$ Citation according to Rolf Wägenbaur, EU-Kommission plant Modernisierung des

Unternehmensrechts, 36 ZEITSCHRIFT FÜR RECHTSPOLITIK 343, 343 f. (2003). 
Capital maintenance and formation shall be simplified on the basis of the SLIM recommendations as supplemented in the "Winter report". The "SLIM-plus" Simpler Legislation for the Internal Market - proposals aim at a modernisation of the acquisition of own shares, management buy out, the prohibition of issuing shares without pre-emption rights and of the elimination of experts' valuations for contributions in kind. Initiatives aiming at improving the financial and nonfinancial information disclosed by company groups and pyramids in the form of an amendment to a Directive are short-term priorities as well. Further, the Commission intends to present a new proposal for a Tenth Company Law Directive facilitating mergers between companies from different Member States, as well as a proposal for a Fourteenth Company Law Directive on the transfer of seat. The Commission also proposes to launch a feasibility study on the possible introduction of a European Private Company Statute, which would primarily serve the needs of SMEs active in more than one Member State. Finally, the Commission wants to support the ongoing process aimed at the introduction of several European legal forms like the European Association and the European Mutual Society.

Other corporate governance initiatives for the medium term (2006 - 2008) proposed in the Action Plan include achieving better information on the role played by institutional investors in corporate governance; giving further effect to the principle of proportionality between capital and control; offering to listed companies the choice between the unitary and two-tier board structure, and enhancing directors' responsibilities for financial and key non-financial statements. The Commission intends to undertake a study on a real shareholder democracy (one share - one vote) and let the study clarify the consequences of such an approach. With regards to capital maintenance and alteration, the Commission will launch a study into the feasibility of an alternative regime not based on the concept of capital maintenance. The Action Plan advocates a framework rule concerning company groups and pyramids to allow those managing a company belonging to a group to implement a coordinated group policy. Moreover, the need for action against abusive pyramids (i.e. chains of holding companies whose sole or main assets are their shareholding in another listed company) is underlined. The Commission also proposes to simplify some of the requirements under the Third Company Law Directive (national mergers) and the Sixth Directive (national divisions) concerning corporate restructuring of public limited companies. If the feasibility study on the Statute for a European Private Company confirms the need for such an initiative, the Commission will present a proposal for an EPC statute in the medium term as well. Further, with respect to the possible development of a proposal for a Regulation on a European Foundation, the Commission intends to launch a study aiming at assessing in depth the feasibility of such a statute. Finally, the Commission considers increased disclosure requirements for all legal entities with limited liability to be necessary in the medium term.

Regarding long-term priorities (2009 onwards) the Action Plan will offer an alternative to the capital maintenance regime as an amendment to the rules of the Second Directive, if the feasibility study indeed confirms the effectiveness and benefits of an alternative regime. Altogether, the Action Plan wants to provide a dynamic and flexible company law framework to overcome the predominant stagnation of 
European Business Law. Nevertheless, the Action Plan will not have as many outreach effects as the Sarbanes-Oxley Act had in the United States.

Finally a brief note from the German point of view: With special regards to corporate governance, the German public is nowadays greatly concerned with the disclosure of the board of directors' income. Only eleven out of 30 companies within the German Stock Index DAX disclosed the overall spending on the income of each director in 2003. The other 19 companies decided to only disclose the overall spending on the income of the board of the directors as a whole. But the companies arose special annoyance when the public became aware of an alliance-like "agreement to stay silent" about the individual income of each director. This special agreement was especially brought to public attention by the head of the government commission on corporate governance, Theodor Baums.

The German Aktiengesetz (Stock Corporation Act) though, requires companies to give a public statement whether they are enforcing the so-called German Corporate Governance Code. And this German Code includes the need to disclose the individual income of each director. Therefore this special need for disclosure is one of the code's regulations which is rarely enforced among German companies after all. Special emphasis to this conflict was recently added by the criminal law investigations and the criminal law trial regarding the Mannesmann/Vodafone acquisition. The judgment of the district court at Düsseldorf held that bonus payments paid after closing of the transaction in favour of former members of the company board do not represent a criminal offence, but still represent an offence regarding the German Stock Corporation Act.

Therefore, German companies are confronted with demands for a full and strict disclosure of any payments to the individual board members and directors, with special regard to pensions and bonus payments. It is currently even considered to propose an amendment to the German Stock Corporation Act that would require companies to present different payment models for the directors at the shareholder meetings and the payment models would then be decided upon by a shareholder resolution. Recently, the German Minister of Justice even threatened companies to propose such an amendment to the German Stock Corporation Act in case the companies do not comply with existing disclosure requirements until their next general shareholder meetings in the summer of 2005. 


\section{SUMmARY}

This Tour d'Horizon through the European Company and Business Law was aimed at underlining the legal and economic importance of this field of law. At the same time the very dynamic process of the European harmonization of law is just as interesting to acknowledge. The integration of Company Law, Business Law and Capital Markets Law into the European Law has recently gained strong momentum. Therefore the new EC Member States do have a great possibility to participate in the making of legal frameworks for the whole European Community and in the proper harmonization of their legal system. But at the same time the potential for fierce future competition among the legal systems should be kept in mind. 